\title{
The Influence of Emotional Factors in the Purchase of Children Products and Brands
}

\author{
Dr.K.Senthilkumar
}

Assistant Professor, Adigrat University, Adigrat, Ethiopia

Received: 11 April 2018; Accepted: 08 June 2018; Published: 08 September 2018

\begin{abstract}
Decision making is a crucial process which is influenced by many factors in the decisions of a person. Especially the purchase decisions are very costlier whether it is towards a product or a service. When focusing on the children products, the decisions towards the purchase of children products and brands are influenced by many factors. The study focuses on the influence of emotional and rational factors on the purchase of children products and brands. It aims to investigate the factors that influence more in the purchase decisions of children products. By exploring the results this study will help the purchasers to take wise decisions since it will throw a light on the influential factors so that it will initiate the introspection of the purchasers. The research was conducted in Coimbatore city of Tamilnadu state in India with 500 respondents. Using a well structured questionnaire, after a pilot study the required primary data have been collected from the respondents. Using excel analysis tool pack the data obtained were computed and analyzed. The results depict that the rational thinking is increasing with the age in the purchase decisions. The middle income group people are more rational in the purchase decisions towards the children products. As a whole the results show that the emotional factors have more influence than the rational factors in the purchase decision of children products and brands. It implies the purchaser must be aware of the influence of emotional factors to limit it to take wise decisions in the purchase of children products and brands.
\end{abstract}

Index Terms: Emotional Factors, Rational factors, Purchase decision and Children products and brands.

(C) 2018 Published by MECS Publisher. Selection and/or peer review under responsibility of the Research Association of Modern Education and Computer Science.

\section{Introduction}

Purchasing a product or service is influenced by many factors. Purchasers are spending more time and cost while they do purchase. There is a blend of emotional, rational, economic and social factors which have been

* Corresponding author.

E-mail address: 
involved in purchase decisions. Inevitably these factors have their own influence in purchase decisions. Many researchers and scientist have proven the influence of emotions in taking decisions (Chethana Achar, 2012). According to Shultz, R. Bomstein and J. Masling the influence of rational factors is also inevitable((Шулц \& Шулц, 2006). Many scholars argued that purchasing decisions of the customers are more rational. However decision making is highly influenced by both emotional and rational factors. A lot of consumer's choice has been influenced by both rational features as well as emotional features (Wilska, 2003). Swait and Adamowicz (2001) found that the decision behaviors exercised by purchasers can be different from one individual to another because customers may use different approaches to make their choices. Uggla (2001), explains consumer behavior into two different types i.e. cognitive and experience oriented. The consumers who have cognitive behaviour are rational and logical consumers while the experience oriented consumers have more emotional motives for buying a product. Ailawadi et al (2001) studied the effectiveness of marketing drivers of brand equity which indicates emotional drivers are more effective than rational drivers. Jones (1999) observed that greater focus would need to be placed on emotional rather than rational brand values which imply that the purchase decisions are influenced by emotions. The consumers may have more brand loyalty and relationship with some brands especially with children products. While focusing on children products the purchasing decision towards children products might be different from that of other products, which may be influenced by many factors including rational and emotional factors. It seems that in case of children products, parents/ guardians are attracted towards some particular brand. Whether the purchase decisions towards children products are wise and scientific is not questioned yet. The reasons for the consumers purchase decisions in this case are still unanswered puzzles. Thus a clear understanding on the preference of customers and the factors that influences their purchase decisions will help the consumers to revise their decision making process. It will help them to take wise decisions. It will also help the producers to strategize their marketing efforts. Hence the study aims to explore the factors that influence more in the purchase of children products.

\section{Related Works}

The literature review has identified the influential factors in purchase decisions through the vast literatures in recent times. Many researchers have indicated the influential variables in relations to purchase decisions. According to Hiebing (2005) the connection between the emotions and purchase is indispensable. In general brands are purchased between two positions: discount brands with little emotional connection and premium brands with lot of emotional connection (Hiebing, 2005).

Blackwell et al. (2005) pointed out that purchase decisions are influenced by many factors such as store promotion, ambience, degrees of cleanness, the service level, price, value, logistic convenience and retail experience. Best and Coney (2001), the categories of decision-making are nominal, limited and extensive. Howard (1989) regarded the consumer decision-making model with six interrelated variables: message, brand recognition, brand attitude, confidence, intention and purchase. Brand recognition, attitude and confidence are the three core factors that shape a consumer's image of a brand (Wang, 2007)

Ailawadi et al (2001) studied effectiveness of marketing drivers of brand equity which indicates emotional drivers are more effective than rational drivers. A strong positive brand personality may increase emotions in consumers, increase levels of trust and loyalty, encourage active processing on the part of the consumer, and provide a basis for product differentiation (Travis, 2000). Researchers have paid greater attention to these emotional aspects, such as feelings of connection with a brand (Fournier, 1998), perceptions of closeness of the self to a brand (Fournier, 1998), and feelings of love for a brand (Carroll and Ahuvia, 2006; Fournier, 1998). Scholars have found that emotional aspects are crucial in enhancing relationship quality in that individuals who are emotionally attached to a brand exhibit greater commitment. The core idea of having strong brand personality is to evoke and to increase consumer emotions and bonding with the brand. Customers are more emotional driven while purchasing some kind of products than the others (Thomson et al., 2005).

The role of emotional influences on judgment and purchase decisions is inevitable. Consumers may desire more emotional image attributes in products or brand (Kim et al., 2000). Jennifer S et al (2007) stated that 
incidental discrete emotions produce nuanced effects consistent with underlying appraisal tendencies and thus their carryover effects are sufficiently powerful to alter judgments and choices even when real money is at stake. Evan (1996) stated that an important thing to note is that consumer purchasing decisions are very often based on normative and emotional factors rather than purely rational justifications.

Imam (2013) suggested that female are more emotional which influences their purchase decisions a lot. According to Batra and Ahtola (1990) the purchase decisions may be based on either emotional or rational factors). Kinner, (2001) found that time expenditure; personality and attitude may affect purchase decision of final consumer either directly or indirectly. Rational factors like price and changes in the price play an influential role in purchase decisions. Dalqvst and Linde (2002) found that the rational factors as one of the leading factors that influences purchase decisions. Dickson and Sawyer (1990) investigated price recall in conjunction with price checking behaviour inside the store, Le Boutillier, Le Boutillier and Neslin (1994) have concentrated on price recall and found that price recall has high influence on the purchase decisions of the shoppers. In a recent study of shoppers' selection of an outlet at which to make a purchase, price was consistently stated as a major influencing factor (as cited by Zsofia Kensei and Sarah, 2003). Such a finding is consistent with the feelings of retailers themselves. Agárdi and Bauer (2000) found that price is an important selection criterion for shoppers. There have been suggestions about overestimation of shoppers' price awareness and response to promotions (Urbany et al., 1996). Research conducted by Urbany and Dickson (2000) based on a representative samples of both retailers and shoppers providing an estimate concerning price awareness and sensitivity in terms of actual level and the level assumed by managers, suggests that retailers greatly overestimated the number of shoppers who actively search for price information. Duwuri et al. (2007) also suggest that consumers' price sensitivities are strongly and positively correlated across product categories. Danes et al. (2012) emphasized that the role of perceived substitute effect is high when the price sensitivity increases. The survey results proved that each person requires price incentives (increase or decrease) to choose another product than the one initially preferred, depending on personal and situational factors. Lockie (2002) found that people prefer organic products due to the avoidance of pesticide residues and they felt the organic product will do better for their health. Lockie's findings proved that the rational behavior of consumers. Molyneaux (2007) supported the positive relationship between heath consciousness and price. According to D. Shultz, R. Bomstein and J. Masling the new non consciousness towards purchase decisions is rational rather than emotional

Harrel (2005) found that purchasing decisions are affected by the factors viz marital status, family and taste. Children themselves play a critical role in purchasing decisions. Children as an influencing agent, achieve increasing influence on buying of various kinds of products (McNeal J,1999). The various researches undertaken already have revealed the influence of emotional and rational factors in purchase decision. Yet the researches are not more specific with children products. Hence the study aims to reveal the factors that have high influence on the purchase decision of children products.

\subsection{Objectives of the Study}

The key objectives of the study are

- To ascertain the influence of emotional factors in the purchase decision of children products

- To ascertain the influence of rational factors in the purchase decision of children products

- To investigate the relationship among age, emotional and rational factors in the purchase decision of children products

- To investigate the relationship among income, emotional and rational factors in the purchase decision of children products

- To compare the influence of emotional and rational factors in the purchase decision of children products 


\subsection{Conceptualization of the Terms and Model}

The definition and meaning of exclusive terms used in the study are below briefed.

\section{Emotional factors}

The factors that are more emotion based which influence a person to prefer a particular brand are termed emotional factors. The emotional factors which have more influence on the decision of children products and brands derived from the literatures for the study are happy, pride, enthusiasm, trendy, surprise, conformity, fun and sentiments are emotional factors

\section{Rational factors}

The factors that are logical and cognitive based which influence a person to prefer a particular brand are termed rational factors. The rational factors which have more influence on the decision of children products and brands derived from the literatures for the study are prize, ingredients, quality, value for money, health consciousness, service, savings intention and lack of opportunity are considered as rational factors.

\section{Purchase decision of children products and brands}

The 'purchase decision of children products' refers to the decision of the purchasers towards the purchase of children products and brands

\section{Children Product and Brands}

The brands which are highly and exclusively used by the children are termed as children product brands. The children product brands considered in this study are Pampers, Chicco, Jhonson \& Johnson, Funskool, Biba Girls, Cute Walk, Fab \& Funky, Mickey Mouse, Faber Castell and Junior Horlicks

\section{Conceptual Model}

Though many variables influence purchase decision, the researcher constructed and limited with sixteen variables that influence the purchase decision of children products from the vast literature review. Accordingly eight variables in each category i.e emotional and rational were considered in the study to find their influence on the purchase decision of children products and the model has been developed.

\subsection{Scope and Limitations of the Study}

This study was limited to the geographical area Coimbatore in Tamilnadu. The study was conducted among the limited number of customers (500 customers). Cross sectional data was collected for the study in January and February 2018 which may limit the results for the particular period. The study attempted to reveal and compare the influence of emotional variables and rational variables in the purchase of children products. Only ten brands of children products were taken for study. The study considered only eight variables for each category viz emotional and rational factors in purchase decisions. The influence of the other extraneous variables was not considered. There may be the influence of other extraneous variables in the purchase decision which were not included in the study. Hence the results cannot be generalized due to the reasons said above. 


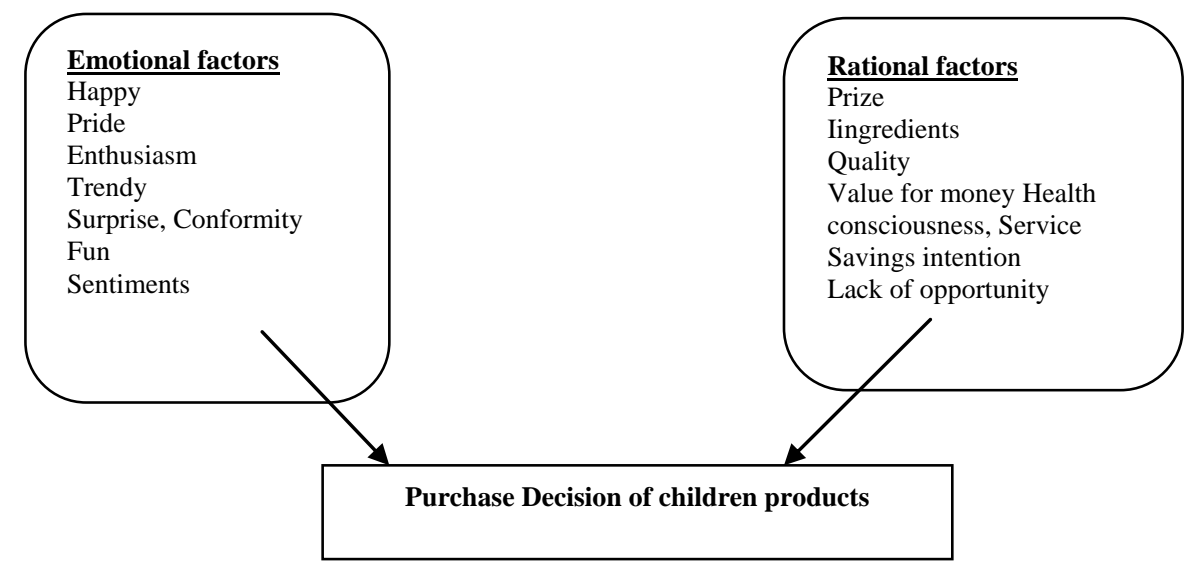

Fig.1. Source: Model Developed by the Researcher

\subsection{Research Design and Execution}

This study aimed to explore the factors influencing purchasing decisions, especially investigating the influence of emotional and rational factors on the purchasing decisions of children products. This study was conducted in Coimbatore city among 500 respondents who purchased the children products during the study period January and February 2018. A well structured questionnaire was designed to collect the data after a profound discussion with the experts. After a vast literature review and discussion with experts the researcher has derived eight variables viz happy, pride, enthusiasm, trendy, surprise, conformity, fun and sentiments as emotional factors that influence the purchasing decision of the buyers on children products and brands. Prize, ingredients, quality, value for money, health consciousness, service, savings intention and lack of opportunity were the variables derived as rational factors to measure the influence the purchasing decision of the buyers on children products and brands. The ten well known children brands such as Pampers, Chicco, Jhonson \& Johnson, Funskool, Biba Girls, Cute Walk, Fab \& Funky, Mickey Mouse, Faber Castell and Junior Horlicks were the brands included to test the influence of emotional and rational factors. The questionnaire contained close ended questions pertaining to the study with Likert scale to measure the influences of the factors in the purchase decision of children products specified. A pilot study was conducted to validate the questionnaire with 50 respondents. Then the required data was collected from 500 respondents. The respondents were the purchasers of the brands under study. The respondents were selected on random basis i.e. simple random sampling method was used to collect the data. The data obtained were computed and the required statistical tests were computed. The statistical tools such as frequency, mean, percentages, correlation and ' $\mathrm{t}$ ' test were used to analyze the data by administering excel analysis tool pack.

\subsection{Research Hypothesis}

Following hypothesis was framed to find the influential nature of the factors

Ho: There is no statistical difference between the influence of emotional factors and rational factors on purchasing children product brands.

Hi: There is a statistical difference between the influence of emotional factors and rational factors on purchasing children product brands.

' $t$ ' test was used to test the hypothesis framed to study and compare the influence of emotional and rational factors. 


\section{Results and Discussions}

The computed data were analysed using excel data analysis tool pack. The demographic characteristics of the respondents have been analyzed first. The influence of emotional factors and rational factors in the purchase decision of children products were analyzed tabulated and discussed. Further the formulated hypothesis was tested using ' $t$ ' test to find the statistical differences between the influence of emotional and rational factors in the purchase decision of the children products.

\subsection{Demographic Characteristics of the Respondents}

The demographic characteristics of the respondents show the distribution of the age, income, sex and marital status of the responds.

Table 1. Demographic Characteristics

\begin{tabular}{|c|c|c|c|c|c|c|c|c|c|c|c|c|c|c|}
\hline 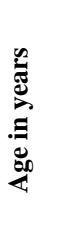 & 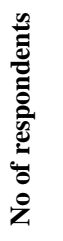 & & 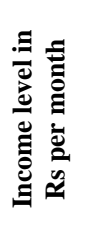 & 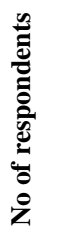 & & 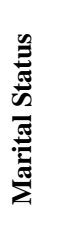 & 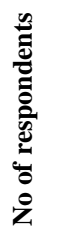 & 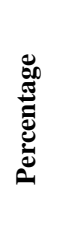 & 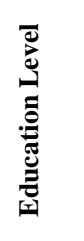 & 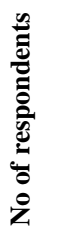 & 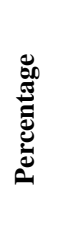 & 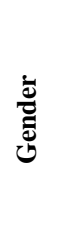 & 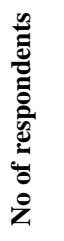 & \\
\hline $\begin{array}{c}\text { belo } \\
\text { w } \\
25 \\
\text { Yea } \\
\text { rs }\end{array}$ & 32 & 6.4 & $\begin{array}{l}\text { Belo } \\
\text { w15 } \\
000\end{array}$ & 61 & 12.2 & $\begin{array}{l}\text { Un } \\
\text { mar } \\
\text { ried }\end{array}$ & 64 & 12.8 & $\begin{array}{c}\text { Belo } \\
\text { w } 12 \\
\text { th } \\
\text { std }\end{array}$ & 76 & 15.2 & $\begin{array}{c}\mathrm{Mal} \\
\mathrm{e}\end{array}$ & 264 & 52.8 \\
\hline $\begin{array}{c}\text { Bet } \\
\text { wee } \\
\text { n } 25 \\
\text { to } \\
35\end{array}$ & 266 & 53.2 & $\begin{array}{c}1500 \\
0 \text { to } \\
2500 \\
0\end{array}$ & 247 & 49.4 & & & & $\begin{array}{c}\text { Bach } \\
\text { elor } \\
\text { degr } \\
\text { ee }\end{array}$ & 321 & 64.2 & & & \\
\hline $\begin{array}{c}\text { Bet } \\
\text { wee } \\
\text { n } 35 \\
\text { to } \\
45\end{array}$ & 124 & 24.8 & $\begin{array}{c}2500 \\
0 \text { to } \\
4000 \\
0\end{array}$ & 175 & 35 & $\begin{array}{l}\text { Mar } \\
\text { ried }\end{array}$ & 436 & 87.2 & $\begin{array}{c}\text { Mast } \\
\text { er } \\
\text { Degr } \\
\text { ee }\end{array}$ & 103 & 20.6 & $\begin{array}{c}\text { Fem } \\
\text { ale }\end{array}$ & 246 & 47.2 \\
\hline $\begin{array}{c}\text { Abo } \\
\text { ve } \\
45\end{array}$ & 88 & 17.6 & $\begin{array}{c}\text { Abo } \\
\text { ve } \\
4000 \\
0\end{array}$ & 17 & 3.4 & & & & $\begin{array}{l}\text { Abo } \\
\text { ve } \\
\text { mast } \\
\text { er } \\
\text { degr } \\
\text { ee }\end{array}$ & - & - & & & \\
\hline $\begin{array}{c}\text { Tot } \\
\text { al }\end{array}$ & 500 & 100 & Total & 500 & 100 & $\begin{array}{c}\text { Tot } \\
\text { al }\end{array}$ & 500 & 100 & Total & 500 & 100 & $\begin{array}{c}\text { Tot } \\
\text { al }\end{array}$ & 500 & 100 \\
\hline
\end{tabular}

The above table shows that most of the respondents are in the middle ages since 78 percent of the respondents are between 25 to 45 years. It indicates that the children products purchasers are in the middle ages. Their monthly income is between 15000 to 45000 rupees. This implies the nature of economy distribution of the society under study. 87.2 percent of the respondents are married. This statistics shows that the children product purchasers are mainly the married people. The rest of the respondents are 12.8 percent. It indicates that the unmarried people are not highly motivated to purchase the children products. The education level of the 
respondents is mixed. The major portion of the respondents (64.2 percent) has got bachelors degree. Only very less percent of the respondents (15.2 percent) are at below $12^{\text {th }}$ standard level. This statistics shows that the purchasers of the children brands are educated in the study area. Irrespective of the gender both male and female purchase children products which can be inferred from the percent proportion 52.8 and 47.2 respectively. However all the above demographic factors may have their own influence on the purchase decision of children products but it is not studied by the researcher since it is beyond the scope of the paper.

\subsection{Influence of the Emotional Factors on the Purchase Decision of Children Products}

The influence of emotional factors on the purchase decision is studied by a Likert five point scale. The responses were scaled from 1 to 5 . The results have been tabulated in table 2 . The mean scores in the table indicates the scores resulted from the responses out of the maximum score 5. Higher the mean values show the higher influence of the variable under study.

Table 2. Influence of the Emotional Factors in the Purchase Decision

\begin{tabular}{lllll}
\hline S.No & Factor & Mean & Std. Deviation & Skewness \\
\hline $\mathbf{1}$ & Happy & 3.58 & 1.13 & 0.12 \\
$\mathbf{2}$ & Pride & $4.68^{*}$ & 0.47 & -0.78 \\
$\mathbf{3}$ & Enthusiasm & 3.63 & 1.10 & 0.15 \\
$\mathbf{4}$ & Trendy & $4.78^{*}$ & 0.48 & -0.65 \\
$\mathbf{5}$ & Surprise & $4.65^{*}$ & 0.47 & -0.78 \\
$\mathbf{6}$ & Conformity & 4.45 & 0.82 & -1.44 \\
$\mathbf{7}$ & Fun & 4.63 & 0.48 & -0.56 \\
$\mathbf{8}$ & Sentiments & $4.65^{*}$ & 0.48 & -0.62 \\
$\mathbf{9}$ & Total score & 35.87 & 3.82 & 1.40 \\
\hline
\end{tabular}

The table above shows the influence of emotional factors which were rated for a maximum score of 5. The results show that among the emotional factors trendy plays a vital role in purchase decision of children products since it scores a mean score 4.78 out of 5 . It is since the parents or the buyers felt the trend and purchase the products for their children. I.e. either the purchasers might have been influenced by their children or by the social group like friends and neighbors. Cinque and Sabato (2009) confirmed the influence of trendy in purchase decisions. Pride also plays a vital role in purchase decisions. Many of the children brands are expensive. Still the buyers feel purchasing such brands to their children is more prestigious to them. It is indicated by a high mean score 4.68. The mean score found for the factor surprise is 4.65 which is relatively high. This score indicates the fact that the parents, friends of parents and relatives generally feel to give gifts to children surprisingly. Sentiments are equally influencing the purchase decisions with a mean score of 4.65. It depicts the fact about the nature of the buyers sentimental feelings much influence the purchase decisions. Jennifer S. Lerner et al (2014) also confirmed the influence of pride and surprise in purchase decisions. It is quiet interest to see that the standard deviations for the factors (trendy, pride, surprise and sentiments) discussed above are less than 0.5. It shows that the degree of variation for the factors mentioned among the 
respondents is very less. Hence it can be inferred that many of the respondents felt trendy, pride, surprise and sentiments are the highly influential factors in their purchase decisions towards the children brands. The influence of the factors fun and conformity cannot be neglected since the factors have scored 4.63 and 4.45 out of 5 respectively. It is clear that the children products are purchased just to conform that their children should also possess the brands as others. Conformity is a main factor in the decision of children products because it scored a mean of 4.45. Yet the high degree of variation (std.deviation) the case is not same for all the purchasers. Some of them gave vary low score to conformity and the others gave high score. Fessler (2007) confirms the influence of conformity in decisions. It is also worth to note that enthusiasm was scored less (mean score 3.63) which implies that enthusiasm has a moderate role in influencing the purchase decision of the children products.

\subsection{Influence of the Rational Factors in the Purchase Decision of Children Products}

The influence of rational factors on the purchase decision is studied by a Likert five point scale. The responses were scaled from 1 to 5 . The results have been tabulated in table 3 . The mean scores in the table indicates the scores resulted from the responses out of the maximum score 5. Higher the mean values shows the higher influence of the variable under study.

Table 3. Influence of the Rational Factors in the Purchase Decision

\begin{tabular}{lllll}
\hline $\mathbf{S . N o}$ & Factor & Mean & Std. Deviation & Skewness \\
\hline $\mathbf{1}$ & Prize & $4.20^{*}$ & 1.10 & -1.14 \\
$\mathbf{2}$ & Ingredients & 2.76 & 0.76 & 0.34 \\
$\mathbf{3}$ & Quality & 3.95 & 1.21 & -0.64 \\
$\mathbf{4}$ & Value for money & 2.76 & 0.87 & 0.43 \\
$\mathbf{5}$ & Healthy & $4.13^{*}$ & 0.95 & -1.04 \\
$\mathbf{6}$ & Service & 2.77 & 0.90 & 0.43 \\
$\mathbf{7}$ & Savings & 2.82 & 0.95 & 0.46 \\
$\mathbf{8}$ & Lack of opportunity & 2.80 & 0.77 & 0.19 \\
$\mathbf{9}$ & Total score & 26.00 & 3.16 & 0.37 \\
\hline
\end{tabular}

Among the variables under study prize is an important and highly influencing variable in the purchase decision of children products which can be inferred form the highest mean score 4.20. It is clear that though it is children products customers are highly prize sensitive. It is ample clear from the table the consumers are highly health conscious too (mean score 4.13) while purchasing children products. Yet this is having high degree of variation. (std. deviation 0.95). Many researchers have confirmed the influence of health consciousness on purchase decisions. For example Mai Ngoc Khuong and Hoang Thi My Duyen found that the consumers show more health attention in the purchase decision of skin care products. This is ample clear form the trend towards purchasing organic products is growing at the fastest rate (Vladimír Vietoris et al, 2016). Other than these above two factors quality is also an important factor to the customers since it possessed a 
mean score 3.95 with a high standard deviation 1.21.. This statistics indicates the quality of the product is highly analyzed by the purchasers of children products before purchasing. However the high standard deviation shows that some of the purchasers do not concentrate more on the quality of the children products. The other factors such as ingredients, savings potential value for money, service and lack of opportunity under study are not highly considered by the purchasers of children products because all the factors mentioned were scored less than 3 out of 5.This shows that the said factors have not influenced more in the purchase decisions of the children products. It is further confirmed by the low standard deviation values. It can be inferred that the opinion of the purchasers of children products is consistent with the various rational factors under study. Over all the statistics shown in the table indicates that the purchasers in general do not purchase the products with rational analysis.

\subsection{Relationship Among Age, Emotional and Rational Factors in the Purchase Decision of Children Products}

The Relationship among age, emotional and rational factors in the purchase decision of children products were tested by correlation coefficients. The data were tested using excel analysis tool pack at 5 percent significance level and the results have been tabulated below.

The results depict many interesting facts regarding the purchase decision towards children products. From the correlation coefficients obtained for emotional factors it is ample clear that age has negative correlation with emotional factors. It shows that when age increases the emotions of the individuals are decreasing in the purchase decision of children products. At the same time it is ample clear the rational thinking is increased with the age which can be inferred from the positive correlations obtained for the rational factors.

Table 4. Relationship among Age, Emotional and Rational Factors

\begin{tabular}{cccc}
\hline S.No & Age in Years & $\begin{array}{c}\text { Correlation } \\
\text { coefficients for } \\
\text { Emotional } \\
\text { factor }\end{array}$ & $\begin{array}{c}\text { Correlation } \\
\text { coefficients } \\
\text { for Rational } \\
\text { factor }\end{array}$ \\
\hline $\mathbf{1}$ & below 25 & -0.05397 & 0.171709 \\
$\mathbf{2}$ & 25 to 35 & -0.14746 & 0.470139 \\
$\mathbf{3}$ & 35 to 45 & -0.33829 & 0.608793 \\
$\mathbf{4}$ & Above 45 & -0.13059 & 0.280457 \\
\hline
\end{tabular}

However the values of the coefficients for emotional factors are less which indicates there is little effect in the emotions with respect to the age. From the age 35 to 45 years the negative correlation is higher $(-0.033829)$ and the corresponding correlation for rational factor is 0.608 . This statistics clearly depicts an interesting fact that at the middle age emotions (from 35 to 45 years) become reduced where as rational thinking is increased. After 45 years the influence of rational factors is little decreasing which can be inferred from the correlation coefficient 0.280457 which is less than the other coefficients c relatively. Below 25 years the influence of rational factor is very less which can be inferred from the lowest correlation coefficient 0.171709 .

\subsection{Relationship Among Income, Emotional and Rational Factors in the Purchase Decision of Children Products}

The rrelationship among income, emotional and rational factors in the purchase decision of children products were tested by correlation coefficients. The data were tested using excel analysis tool pack at 5 percent significance level and the results have been tabulated below. 
Table 5. Relationship Among Income, Emotional and Rational Factors

\begin{tabular}{cccc}
\hline S.No & $\begin{array}{c}\text { Monthly income } \\
\text { in Rs }\end{array}$ & $\begin{array}{c}\text { Correlation } \\
\text { coefficients for } \\
\text { Emotional factor }\end{array}$ & $\begin{array}{c}\text { Correlation } \\
\text { coefficients for } \\
\text { Rational factor }\end{array}$ \\
\hline $\mathbf{1}$ & Below 15000 & 0.097329 & 0.263751 \\
$\mathbf{2}$ & 1500 to 25000 & 0.027446 & 0.529579 \\
$\mathbf{3}$ & 25000 to 40000 & 0.075835 & 0.391376 \\
$\mathbf{4}$ & Above 40000 & 0.067361 & 0.196822 \\
\hline
\end{tabular}

The results shows that there is a little positive correlation between income and emotions whereas relatively higher positive correlation between income and rational thinking. i.e when income increases it is interest to look that the rational thinking is increasing in higher steep than that of emotions. It is also interest to notice that between 15000 to 25000 monthly income group the correlation coefficient is the highest ( 0.529579$)$ and also between 25000 to 40000 monthly income group the correlation coefficient is relatively higher $(0.391376)$ This statistics implies that the middle income group people are more rational and cost conscious when income increases while purchasing children products. But the same situation is not reflected in the low and upper income group people which can be inferred from the correlation coefficients 0.263751 and 0.196822 respectively. In the low income group the emotions increased when income increases which can be inferred from the relatively higher coefficient 0.097329 . The relationship between income and emotions are negligible since the coefficients are very less.

\subsection{Influence of Emotional and Rational Factors in the Purchase Decision}

The main objective of the study is to find the influence of rational factors as well as the emotional factors in the purchase decision of the children products. It is inferred from the research that both rational and emotional factors do highly the influence the purchase decision of children products in a combined manner because the respondents have rated both the factors as the leading factors for their purchase decision towards children products.

Table 6. Influence of Emotional and Rational Factors in the Purchase Decision

\begin{tabular}{lll}
\hline Statistics & Emotional factors & Rational factors \\
\hline Mean Total & 34.9467 & 26.0000 \\
Mean of the means & 4.36 & 3.25 \\
Variance & 6.5743 & 9.9597 \\
Observations & 500 & 500 \\
Pooled Variance & 8.267025 & \\
Hypothesized Mean Difference & 0 & \\
Degrees of Freedom & 998 & \\
t Statistics & 26.945 & \\
P(T<=t) two-tail & $7.11 \mathrm{E}-82$ & \\
t Critical two-tail & 1.967 & \\
\hline
\end{tabular}


However to study the statistical differences, ' $\mathrm{t}$ ' test was conducted using excel tool package at 5\% significance level. The important results have been shown in the below table.

When comparing the mean values of the emotional and rational factors in the above table one can easily infer the influence of emotional factors are higher than the rational factors in the purchase of children products. (the total mean values are 34.9 and 26 respectively for maximum of 50). The mean of the mean values for the emotional and the rational factors are 4.36 and 3.25 respectively. The scores indicate that the emotional factors influence more and play a vital role in the purchase decision of the children products. However to test the formed hypothesis to find the statistical differences between the emotional and rational factors ' $t$ ' test was conducted. The ' $t$ ' statistics clearly indicates that there is a statistical difference between the emotional and rational factors. The 't' critical value for a two tailed test is 1.967 whereas the statistic value is 26.945 . Hence the null hypothesis is rejected and alternative hypothesis is accepted. It is very clear that there is a statistical difference between the influences of emotional factors and rational factors. The result shows that the influence of emotional factors is more than the influence of rational factors in the purchase decision of children products. This throws a light for thinking the purchase decisions of the consumers on the children products. The purchasers are more emotional than rational and they do purchase without proper rational analysis.

The results clearly indicate while taking decision towards the purchase of children products the purchasers are more emotional and they do not give more importance to rational things. The purchasers are more emotional because of the emotions they have with the children. The purchase decisions may not wise since the purchase decisions towards the children products are not much rational. Hence the purchasers of children products should focus on rational factors too to have a good purchase of children products and brands.

\section{Conclusion}

The study throws a light on the purchase decision of children products and brands. Though the purchasers take an account of both emotional and rational factors in their purchase decisions the influence of emotional factors are more than the rational factors. Hence the study suggests the purchasers of children products to be more rational which may lead to wise decisions on the children products and brands.

\section{References}

[1] Agárdi, Irma - András Bauer (2000): Az élelmiszer-kiskereskedelem szerkezeti változásai és kialakult vállalatcsoportok Magyarországon. (Structural Changes and Strategic Groups in the Hungarian Grocery Retailing ) Marketing \& Menedzsment, 3, 8-14.

[2] Ailawadi, K. L., D. R. Lehmann, S. A. Neslin. (2001), Market response to a major policy change.

[3] Batra, R and Ahtola, OT (1990). Measuring the hedonic and utilitarian sources of consumer attitudes, Marketing Letters, vol. 2, no. 2, pp. 159-170.

[4] Blackwell, Roger D., Paul W. Miniard and James F. Engel (2005), Consumer Behavior (10th), Thomson Learning.

[5] Carroll, B.A. and Ahuvia, A.C. (2006), "Some antecedents and outcomes of brand love", marketing Letter, Vol. 17 No. 2, pp. 79-89.

[6] Chethana Achar (2012). What we feel and why we buy: the influence of emotions on consumer decision-makin, Current Opinion in Psychology 2016, 10:166-170.

[7] Cinque, Sabato. (2009) Interview. (Conducted by Jay Dickieson \& Victoria Arkus). 2 August 2009. Plymouth, UK.

[8] Danes, Jeffrey E. and Joan Lindsey-Mullikin. 2012. "Expected product price as a function of factors of price sensitivity", Journal of Product \& Brand Management, 21(4): 293-300.

[9] Dickson P. R. and A. G. Sawyer (1990): The Price Knowledge and Search ofSupermarket Shoppers. Journal of Marketing, 54 (July), 42-53. 
[10] Duwuri, Sri Devi, Asim Ansari and Sunil Gupta. 2007. "Consumers' Price Sensitivities Across Complementary Categories", Management Science, 53(12): 1933-1945.

[11] Evans D. L, Mayer, J. D., Gaschke, Y. N. \& Braverman,. T. W (1992). Mood-congruent judgment is a general effect. Journal of Personality \& Social Psychology, 63, 119-132.

[12] Evans, M., Jamal, A. \& Foxall, G. 2006. Consumer Behaviour. John Wiley \& Sons Ltd. West Sussex.

[13] Evans, M., Moutinho, L. \& Van Raaij, W. F. 1996. Applied Consumer Behaviour. Addison Wesley Publishing Ltd. Cornwall.

[14] Fournier, S.M. (1998), "Consumers and their brands: developing relationship theory in consumer research", Journal of Consumer Research, Vol. 24 No. 4, pp. 343-73.

[15] Hawkins, Del I., Roger J. Best and Kenneth A. Coney (2000). Consumer Behavior: Building Marketing Strategy, 8/e, McGraw Hill Company.

[16] Hiebing, (2005) Emotional Connection Can Build Strong Brands Seven Ways https://www.hiebing.com/wp-content/uploads/2009/10/4_EmoConnection.pdf retrieved on February 2018.

[17] Howard, John A. (1989). Consumer behavior in marketing strategy New Jersey: Prentice-Hallin the marketing mix: Learning from Procter \& Gamble's value pricing strategy. J. Marketing (January) 44-61.

[18] Шулц, Д., \& Шулц, С. (2006). История на модерната психология. София.

[19] Jennifer S (2007). Feelings and Consumer Decision Making: The Appraisal-Tendency Framework, Journal of consumer psychology, 17(3), 158-168.

[20] Jones, J., 1999. The future of banking: Implications of branding and loyalty. Journal of Financial Services Marketing 3, 53-66, 1999.

[21] Kim J-O, Forsythe S, Gu Q and Moon S J (2002), "Cross-Cultural Consumers Values Need and Purchase Behavior", Journal of Consumer Marketing, Vol. 19, No. 6, pp. 481-502.

[22] Le Boutillier, John, Susanne Shore Le Boutillier, and Scott A. Neslin (1994): A Replication and Extention of the Dickson and Sawyer Price Awareness Study. Marketing Letters, 5 (1), 31-42.

[23] Lockie, S., K. Mummery. (2002) "Eating Green: Motivations behind organic food consumption in Australia" Sociologia Ruralis 42(2002) Pp.23-40.

[24] Molyneaux, M. (2007) "The Changing Face of Organic Consumers" Food Technology 61(2007): Pp.2226.

[25] Neal, C. M., Quester, P. G., \& Hawkins, D. I. (2002). Consumer behavior: Implications for marketing strategy (3rd ed.). Australia: McGraw-Hill.

[26] Rao, H. Raghav, Dan Jong Kim and Bongsoon Cho (2000), Effects of Consumer Lifestyles on Purchasing Behavior, "Proceedings of the twenty first international conferences on Information systems, Brisbane, Queensland, pp. 688-695.

[27] Swait, J and Adamowicz, W (2001). The influence of task complexity on consumer choice: A latent class model of decision strategy switching, Journal of Consumer Research, vol. 28, no. 1, pp. 135-148.

[28] Thomson, M., MacInnis, D.J. and Park, C.W. (2005), "The ties that bind: measuring the strength of consumers' emotional attachment to brands", Journal of Consumer Psychology, Vol. 15 No. 1, pp. 53147.

[29] Travis, Deryl,(2000) Emotional Branding: How Successful Brands Gain the Irrational Edge, Crown Publishing Group, 2000.

[30] Uggla, H. (2001) Organisation av varumärke, Malmö: Liber Ekonomi., Sweden.

[31] Urbany, J. E., P. R. Dickson and A. G. Sawyer (2000): Insights Into Cross- and Within-Store Price Search: Retailer Estimates vs. Consumer Self Reports. Journal of Retailing, 76 (Summer), 243-254.

[32] Urbany, J. E., P. R. Dickson and R. Kalapuracal (1996): Price Search in the Retail Grocery Market. Journal of Marketing, 60 (April), 91-104.

[33] Vladimír Vietoris et al (2016), Analysis of Consumer Preferences at Organic Food Purchase in Romania, Pol. J. Food Nutr. Sci., 2016, Vol. 66, No. 2, pp. 139-146.

[34] Wang, Sheng-Pi (2007). The Study of Consumer Innovativeness Facilitates New Product Adoption: An 
Integrating Individual and Family Perspective. Master's Thesis, Graduate School of Management, Ming Chuan University.

[35] Wilska, TA (2003). Mobile phone use as part of young people's consumption styles, Journal of Consumer Policy, vol. 26, no. 4, pp. 442-464.

[36] Zsofia Kensei and Sarah Todd (2003). The Use of Price in the Purchase Decision, Journal of Empirical Generalizations In Marketing Science 81-21.

\section{Authors' Profile}

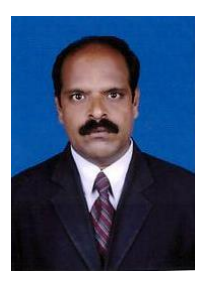

Dr. K.SenthilKumar received the B.E (Mechanical Engineering) from GCT, Coimbatore and M.B.A from Periyar University.in 1994 and 2001 respectively. He received Ph.D in Management from Gandhigram Rural University in the year 2013. He is currently working as Assistant Professor in Management department, Adigrat University. His area of research includes Marketing, HRM and Operations. He has presented many papers in national and international conferences. He has published eight papers in international journals. He may be reached at senthilkumar.kalyan@gmail.com

How to cite this paper: K.Senthilkumar,"The Influence of Emotional Factors in the Purchase of Children Products and Brands", International Journal of Education and Management Engineering(IJEME), Vol.8, No.5, pp.18-30, 2018.DOI: 10.5815/ijeme.2018.05.03 